\title{
Література:
}

1. Балл Р.О. Сучасний гуманізм і освіта: Соціально-філософські та психолого-педагогічні аспекти. - Рівне : «Ліста-М», 2003. - 340 с.

2. Булах I.С. Специфіка особистісного зростання підлітка: ракурс сучасного психологічного дослідження // Журнал практикуючого психолога. - 2002. - Випуск 8. - С. 72-85.

3. Костюк Г.С. Навчально-виховний процес і психічний розвиток особистості. - К. : Наукова думка, 2002. - 250 с.

4. Максименко С.Д. Психологія в соціальній та педагогічній практиці. - К. : Наукова думка, 1998. - 410 с.

5. Організація психологічної служби : навч.-мет. посіб. О.Я. Митник, Т.В. Середюк. - К. : Видавничий Дім «Слово», 2017. $128 \mathrm{c}$.

\section{DOI https://doi.org/10.30525/978-9934-26-041-4-3}

\section{СТРЕСОСТІЙКІСТЬ ОСОБИСТОСТІ У КОНТЕКСТІ ЇЇ АДАПТАЦІЙНОГО ПОТЕНЦІАЛУ}

\author{
Грилюк С. М.
}

викладач кафедри морально-психологічного забезпечення

діяльності військ (сил)

Національний університет оборони України

імені Івана Черняховського, аспірант

ПВНЗ «Університет сучасних знань»

м. Київ, Украӥна

Тютюнник Л. Л.

ад 'юнкт гуманітарного інституту

Національний університет оборони Украӥни імені Івана Черняховського

м. Київ, Украӥна

У сучасних умовах війни на Сході України гостро постає питання підвищення стресостійкості особистості з урахуванням iï адаптаційного потенціалу до бойових умов, а у подальшому їх реадаптації до умов мирного життя. 
У бою людина діє, насамперед, згідно власної природи - інстинктам самозбереження, але вся система бойової (оперативної) підготовки має бути спрямована на пригнічення цієї природи, й спонукати діяти всупереч іiі, готувати військовослужбовців діяти згідно суспільних цілей та інтересів захисту Батьківщини [4, с. 8]. Незважаючи на те, що у бойовій обстановці у воїнів спостерігається зміна психічних станів, що охоплює емоційну, поведінкову, фізіологічну й когнітивну складові, рівень їхньої підготовки (готовності) має забезпечити виконання бойових завдань у будь-яких умовах. При цьому враховуються усі стресори бойової обстановки та їх потенційний вплив, швидкість адаптивних реакцій військовослужбовців, їхню стресостійкість, наполегливість, мужність, хоробрість та інші індивідуальні особливості.

Поведінкові реакції воїнів на прикладі зміни перебігу мисленнєвих процесів при стресових реакціях умовно поділяють на три типи: активізація мислення; зростання стресової пасивності мислення уникання особистості від вирішення екстремальної проблеми та стресове підвищення продуктивності мислення без помітної зміни емоційної поведінки та рефлексії $[1$, с. 46].

У залежності від сили стресора у військовослужбовців спостерігається гальмування мислення, що проявляється у завмиранні тіла на фізичному рівні та пошуку у пам'яті схожих ситуацій. Якщо стресор меншої інтенсивності, або екстремальна ситуація $є$ звичною, у особистості активується контрольоване розумом дискурсивне мислення, яке орієнтується на раніше вивчені інструкції та набуті професійні навички. 3 початком дії стресора активуються й інші когнітивні функції: пам'ять, сприймання, розуміння, усвідомлення, перероблення інформації тощо [1, с. 47-51].

За умови, коли стресор, або екстремальна ситуація $\epsilon$ незнайомою, а у пам'яті немає програм для його подолання - тоді особистість реагує на стресовий чинник пасивно i спостерігається загальмованість усвідомлення та уникання від вирішення проблеми, що виникла, або заміна її менш значимими [1, с. 53 - 54].

Особам з високою стресотійкістю властива швидка адаптація до негативного впливу стрес-чинників, конструктивна активізація мислення 3 відбором необхідної інформації, яка співставляється 3 професійними знаннями та раніше набутим життєвим досвідом. У таких військовослужбовців стрес мобілізує фізіологічні ресурси і забезпечує довготривалу невтомність мислення [1, с. 68].

Вплив стресу чітко прослідковується у емоційно-поведінкових та фізіологічних проявах. У стресових ситуаціях при короткочасному інтенсивному впливі стресора виділяють чотири основні типи реакції: 
перші дві характеризуються або посиленням, або послабленням емоційно-поведінкової активності; третя - конструктивним реагуванням на стрес, а четверта - стресово-нейтральна група (особи, які за відсутністю досвіду, не можуть усвідомити небезпеку, що насувається) $[2$, c. $55-56]$.

За умов незначного але довготривалого впливу стрес-чинників на початковому етапі спостерігається пожвавлення емоцій, активізація рухливості та когнітивних функцій. 3 часом рухливість та працездатність зменшується, з'являється м'язова втома, апатія, знижується увага тощо. Довготривалість перебування у зміненому фізіологічному стані, яка відрізняється від норми збільшує вірогідність того, що стресова реактивність обернеться для людини психосоматичним або соматоформним захворюванням. У бойових умовах тривожність, надмірна рухова активність або навпаки відчуженість й уповільненість рухів, блідість та почервоніння обличчя, надмірне потовиділення свідчать про низьку нервово-психічну стійкість. Чим триваліший стресовий вплив, тим ці прояви виразніші [2, с. 77 - 84, 266; 4, с. 12 - 20].

$\mathrm{y}$ сучасних дослідженнях, визначаючи підготовленість військовослужбовця до бойових дій, наголошується на важливості визначення (діагностики) його відповідних функціональних станів та прогнозного оцінювання бойової активності у відповідних умовах.

У визначенні потенціалу особистості військовослужбовця до мінливих факторів бою важливу роль відіграє нейрогуморальна регуляція системи кровообігу та координація вертикального положення тіла при стоянні. Оцінювання рівня стресостійкості, адаптаційного потенціалу та резерву організму військовослужбовців ми можемо здійснювати за показниками варіабельності серцевого ритму та дослідження статичної просторової стійкості (стабілографія) [5, с. 46 - 51]. Зазначені методи дослідження потребують біля 5 хвилин, що є важливим в умовах дефіциту часу.

На нашу думку характеристики адаптивних процесів та показники стресостійкості особистості в бойових умовах можна суттєво посилити за допомогою заходів неформальної підготовки, зокрема психоедукаційних заходів, заходів самоосвіти, розвитку практичних навичок для подолання стресу тощо.

Сьогодні, поряд 3 традиційними формами психологічної роботи у військах (силах), варто використовувати нові практики для підвищення стресостійкості особистості, зокрема застосування кінезіологічних практик, акупресури, кольоротерапії, ароматерапії та ін. Кожна із цих практик має своє цільове застосування. 
Значний терапевтичний ефект на стан людини здійснює кінезіологічна зарядка. Завдяки цій методиці людина самостійно відновлює тонус м'язів, які пов'язані з функціональними структурами та органами тіла, що позитивно впливає на психоемоційний та фізичний стан людини. Причому ефект впливу спостерігається одразу $[3$, c. $356-361]$.

Акупресура передбачає вплив на біологічно активні точки на тілі людини, шляхом їх притискання рукою, впливаючи на лінії меридіанів, які пронизують організм людини й пов'язані з усіма органами та системами [3, с. 356 - 361].

Ефективним методом впливу на організм людини 3 метою відновлення гомеостазу $є$ кольоротерапія, оскільки колір викликає певні біохімічні реакції у тканинах тіла людини, стимулює роботу різноманітних залоз та відділів головного мозку, зокрема гіпофізу. Різні кольори стимулюють вироблення гіпофізом ряду гормонів, які відповідають за обмін речовин, сон, апетит, емоційний стан тощо.

Значний позитивний ефект на психоемоційний стан особистості мають засоби ароматерапії. Натуральні ефірні олії потрапляють в організм людини через дихальні шляхи та через шкіру, здійснюючи асоціативний і рефлекторний вплив [3, с. 340 - 345].

Завдяки вищезазначеним методам значно скорочується термін відновлення усіх систем організму та балансується гомеостаз. Про це свідчать повторні дослідження показників варіабельності серцевого ритму та стабілографії.

Отже, стресостійкість особистості, іiі адаптаційний потенціал, когнітивні оцінки зовнішніх подій, професійний і життєвий досвід, знання, уміння, навички у комплексі визначають ступінь впливу стресогенних чинників на свідомість та психіку. Активна розумова та фізична діяльність в умовах різкої зміни обстановки, високого темпу дій, недостатності інформації, несподіваності, невідомості, відповідальності за виконання бойових завдань і за життя тих, хто поряд, потребують високого рівня стресостійкості та адаптаційного потенціалу особистості.

Hе вирішеним залишається питання віднаходження та впровадження у підготовку особового складу до бойової діяльності простих та ефективних способів саморегуляції та самокорекції.

У наших подальших публікаціях будуть подані результати досліджень підвищення стресостійкості та відновлення адаптаційного потенціалу особистості військовослужбовця через застосування нетрадиційних методів психокорекції. 


\title{
Література:
}

1. Китаев-Смык Л.А. Сознание и стресс: Творчество. Совладание. Выгорание. Невроз. - М.: Смысл, 2015. - 768 с.

2. Китаев-Смык Л.А. Организм и стресс: стресс жизни и стресс смерти. - М. : Смысл, 2019. - 464 с.

3. Кодлубовська Т.Б. Психофізіологічні механізми регуляції функціональних станів співробітників правоохоронних органів. : Дис. докт. наук. - Інститут психології імені Г. С. Костюка НАПН України, Київ, 2020.

4. Психолого-корекційний практикум травм війни [Текст] : навч. посіб. / Іван Сулятицький, Катерина Островська, Василь Осьодло [та ін.]; Львів. нац. ун-т ім. Івана Франка, Нац. ун-т оборони України ім. Івана Черняховського. - Львів : ЛНУ ім. Івана Франка, 2019. - 395 с. : рис. Бібліогр.: с. 340-357. - 300 прим. - ISBN 978-617-10-0525-9

5. Стрес-асоційовані розлади здоров'я в умовах збройного конфлікту / В. С. Гічун, А. Г. Кириченко, В. М. Корнацький [та ін.]. Дніпро : Акцент ПП, 2019. - 323 с.

\section{DOI https://doi.org/10.30525/978-9934-26-041-4-4}

\section{ФІЗИЧНА КУЛЬТУРА ТА СПОРТ ЯК ВАЖЛИВІ ДІЕВІ ЗАСОБИ ВИХОВАННЯ ОСОБИСТОСТІ}

\author{
Дейнеко А. X. \\ кандидат наук з фізичного виховання і спорту, дочент \\ Харківська державна академія фізичної культури \\ Рябченко О. В. \\ старший викладач \\ Харківська державна академія фізичної культури \\ Шевчук О. К. \\ здобувач другого (магістерського) рівня вищої освіти \\ Харківська державна академія фізичної культури \\ м. Харків, Україна
}

Термін «особистість» (від лат. persona) має давнє походження. Первісно у це поняття був включений зовнішній, поверхневий соціальний образ, який індивідуальність приймає, коли грає певні 